Saudi Journal of Business and Management Studies Abbreviated Key Title: Saudi J Bus Manag Stud ISSN 2415-6663 (Print) |ISSN 2415-6671 (Online) Scholars Middle East Publishers, Dubai, United Arab Emirates Journal homepage: http://scholarsmepub.com/sjbms/

Original Research Article

\title{
The Analysis of Character Education Policy at State of Madrasah Aliyah Jambi Indonesia
}

\author{
Abdul Halim ${ }^{1}$, Kasful Anwar US ${ }^{1}$, Maisah $^{2}$, Muhamad Taridi ${ }^{1 *}$ \\ ${ }^{1}$ State Islamic University of Sulthan Thaha Saifuddin Jambi \\ ${ }^{2}$ School of Postgraduate of State Islamic University of Sulthan Thaha Saifuddin Jambi
}

DOI: $10.36348 /$ SJBMS.2019.v04i12.004 $\quad$ | Received: 30.11 .2019 | Accepted: 07.12.2019 | Published: 11.12 .2019

*Corresponding author: Muhamad Taridi

Abstract

The purpose of this study was aimed at analysing national education policy on the implementation of character education which contains preparing madrasah, implementing policy, basic policy, as well as supporting and inhibiting factors. The research approach applied descriptive qualitative by collecting data through observations, interviews, and documentation. It was conducted at the State of Madrasah Aliyah (MAN) in Jambi Province. The research subjects consisted of madrasah principal, the vice of the curriculum, teachers, and students. This study revealed that 1) the potential of madrasah including environmental excellence, and evaluation shows the number of hours of learning and adaptive teachers. 2) Implementation of character education policies in madrasah through the learning of character values into learning programs, madrasah programs, and madrasah culture. 3) The basis for the government issuing a national policy on character education is the mandate of the 1945 Constitution, the 2003 National Education System Law, RAN 2010-2014, RPJP 2005 -2025, PP No. 87 of 2017, Ministry regulation No. 20 of 2018, addresses the 8th Nawacita (9 Jokowi-JK priority agenda) by the mental Revolution. 4) Changing in bureaucracy, changes in curriculum content, teacher understanding, and focus are still on cognitive, but community typology is not yet developed, and training is still inefficient. It can be concluded that the character education policy in The State Madrasah Aliyah Jambi Province has been implemented and has not maximally utilized the human resources that become uswatun khasanah figures and provides assistance for learning that supports character education in madrasah.

Keywords: Policy analysis, national policy, character education.

Copyright @ 2019: This is an open-access article distributed under the terms of the Creative Commons Attribution license which permits unrestricted use, distribution, and reproduction in any medium for non-commercial use (NonCommercial, or CC-BY-NC) provided the original author and source are credited.

\section{INTRODUCTION}

Based on the National Education Long-Term Goals set out in Law Number 17 of 2007, the government made a Character Education Policy set forth in Presidential Regulation No. 87 of 2017 concerning Strengthening Character Education. This regulation was subsequently realized by the Ministry of Research and Technology of the Republic of Indonesia in the form of its derivative rules; Regulation of the Minister of Research on Technology and Higher Education Number 20 of 2018 concerning Strengthening Character Education in Formal Education Units. Furthermore, the national policy on educating these characters is understood, realized and implemented partially and differently by formal education units at the State of Madrasah Aliyah level in
Jambi City in accordance with the vision and mission of the madrasa.

The development of educational outputs or demands that are ready to be accepted by various fields of stakeholders occurs because more and more problems are plaguing the world of children both from elementary to adolescent levels. Frequent cases of acts of sexual harassment, violence, bullying, discrimination, and the use of illegal drugs give birth to a question mark on what exactly is character education that has been intensified to be implemented in all educational institutions.

The development of various new strategies within the school such as learning modes that are more 
comprehensive, flexible, and innovative, must take into account the needs of students who are always changing and developing. All developments include changes in education policy to address educational disparities and inequalities that often occur due to socio-economic differences.

The development of strategies is intended to improve the quality of education significantly. Therefore, various efforts were made to obtain a learning pattern in education that suits the needs of students and the growth of the quality of human resources by harmonizing education and local culture. Strengthening education in schools with the support of local culture to preserve the values of students' relationships with the social community. This strategy provides an educational direction characterized by local culture. And to answer more complex challenges, educational institutions collaborate with local learning systems with the cooperation of local governments so that educational policies are equitable with changes and education reforms in all regions.

The various problems faced by the State of Madrasah Aliyah in Jambi Province are very complex. First, the implementation of character education is not as easy as designing character education itself. Child behaviour problems in madrasas that often occur in the inculcation of values of discipline, honesty, and tolerance. Madrasa children who are in their early adolescence and are a phase where they are looking for an identity, do not obey the rules of the madrasa. Attitudes violate the rules of madrasa committed by students as a form of the upheaval of children against regulations that are not approved by their opinions. Discipline attitudes cause students problems so they must receive punishment following their actions.

Second is the existence of smoking habits among madrasa children who fall into the adolescent age category. Students who smoke get the influence of peers when they hang out in the environment outside the madrasa. Smoking habits among madrasa students can endanger social and emotional conditions. Some of the things that are more concerned about these actions could lead to the use of narcotics and illegal drugs. The use of drugs will damage the psychology of children and their mental collapse in the work and build creativity. Children who have used drugs will experience a decreased level of concentration in learning and can have an impact on other friends. Schools crackdown on children who use illegal drugs.

\section{LITERATURE REVIEW Policy Analysis}

Etymologically the word policy (policy) is derived from Greek, which is a policy that means city. Policy also refers to the ways in which all sections of government direct to manage their activities [1]. Policy analysis is a process that can produce technical information as one of the inputs for the formulation of several policy alternatives supported by technical information [2].

The first policy analysis research scientist William N. Dunn proposed key aspects of the methodology of the policy analysis process. The following basic model is the first source of William $\mathrm{N}$. Dunn's writing which is a reference for policy analysis research:

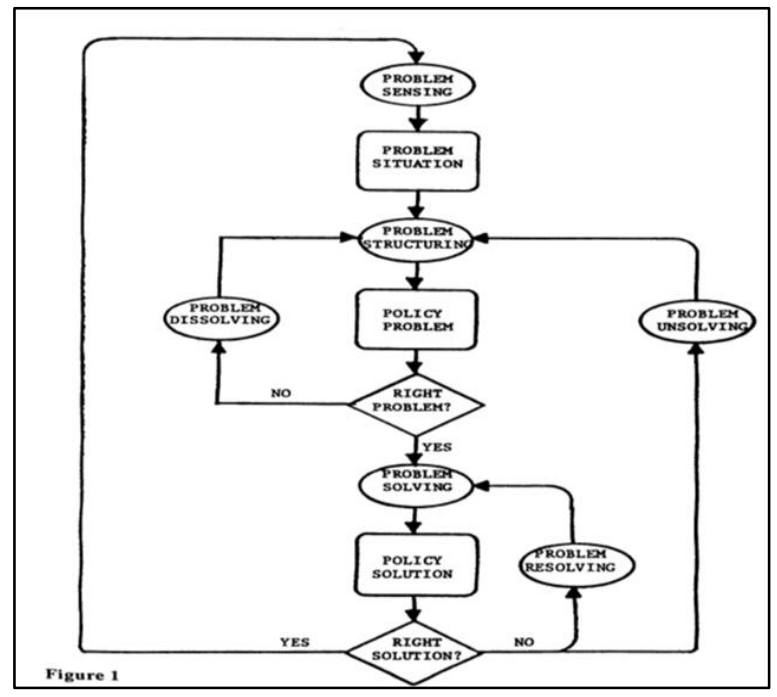

Fig-1: Basic Model of Aspect Methodology Policy Analysis William N. Dunn [3]

In the Islamic perspective, it can be harmonized about the basis of the implementation of the stages of public policy which is based on the Surah alNahl verse 12. The understanding contained in the above verse that Allah commands us to do da'wah and communication with a policy (policy) and the delivery of suggestions or input that is good and right so that it goes as well as possible.

Education policy analysis is a series of decision-making activities based on information that has been obtained in the past to get a change in education in the future. Indicators of education policy analysis are the formulation of educational problems, policy formulations, assessments, and recommendations.

\section{Character Education}

The concept of Islam shows that the word education is mostly referred to the words äl-tarbiyah", äl-ta'lim", and al-ta'dib". Term al-tarbiyah is further defined as: "caring", "bearing", feeding "," developing "," maintaining "," making "," raising "and" taming "[4]. Education in carrying out the function to make changes in behaviour there are values that must be instilled in education, namely mental, moral, physical, and artistic values [5]. 
Character is interpreted as a way of thinking and behaving that is unique to each individual to live and work together, both in the family, community, nation and State.

Character can be considered as values of human behaviour related to God Almighty, self, fellow human beings, environment and nationality which are manifested in thoughts, attitudes, feelings, and words, actions based on religious norms, law, etiquette, culture, customs, and aesthetics [6].

For the school level there are criteria for student character known as the 18 characters of the ministry of education, namely religious, honest, tolerance, discipline, cooperation, creative, independent, democratic, curiosity, national spirit, love of the motherland, respect for achievement, friendship / communicative, love peaceful, like to read, care about the environment, care about social, and responsibility [7].

In the Islamic concept, the command to apply character education for the purpose of conditioning and creating improvements in human behaviour so that it can be better can be digested through our understanding of the verses of the Koran in the letter Ali-Imron verse 104.

Al-Ghazali has laid down four main principles of morality which cause human beings to give birth to commendable morals as quoted by Muhammad Abdurrahman namely Wisdom (wisdom), Fair, Syaja'ah (courage), Iffa [8].

Characters can be developed in two ways, namely the teacher as an example and habituation or civilizing characters in schools. In the class the teacher acts as a facilitator. To develop character, the teacher acts as an example. Characterization will also be successful if the principal acts as a direct controller of the implementation of certain cultures [9].

\section{MATERIAL AND METHODS}

The research approach used was a descriptive qualitative research method with a case study at the State of Madrasah Aliyah (MAN) Jambi Province. The research subjects consisted of madrasah principals, teachers, and students. Data collection instruments used was observation, interviews, and documentation. The research data collected were analysed using the Miles and Huberman formula which consisted of data reduction, data display, and verification or conclusion stages. The validity of the data uses an extension of participation, triangulation techniques, perseverance of observation and peer discussion.

\section{RESULTS AND DISCUSSIONS \\ Some findings in the study consisted of}

Firstly the basics of the government issued a character education policy that is the mandate of Article 31 of the 1945 Constitution; Law Number 20 Year 2003 concerning National Education System; National Action Plan for Character Education, Ministry of National Education, 2010-2014; Presidential Regulation of the Republic of Indonesia, Number 87 of 2017, Regarding Strengthening Character Education; and Regulation of the Minister of Education and Culture of the Republic of Indonesia, Number 20 of 2018, Concerning Strengthening Character Education. And the embodiment of the 8th nawacita is the national character revolution or mental revolution.

Secondly, an analysis of national policies on character education in Madrasah Aliyah in Jambi Province. The results showed that the analysis of national policies on character education at the State of Madrasah Aliyah Jambi province included; the first is the preparation of educational problems in madrasas that involve all elements of madrasah management through meetings that are held routinely every semester by mapping the implementation of policies into activities according to the education calendar. The initial problem identified by the implementer is moral degradation. Moral degradation: ethics towards friends, ethics towards teachers, and ethics using social media. Second, the formulation of policies at the madrasa level. The head of madrasa has the authority to formulate madrasa programs to implement character education policies by looking at the potential of the surrounding area. Initial problem identification is that in the implementation there has not been any special assistance from the local government, the ability of teachers has not been adaptive to environmental potential, and the readiness of teachers as role models is not met. Third, evaluation of policy implementation in madrasas is carried out on all subject teachers. The detected problems are the hours of religious and extracurricular subjects are still less than needed and the limited knowledge of educators in entering character values into learning correctly. Several awards were obtained for educational achievements at Madrasah. Fourth, the recommendations of this analysis are that the Government must be underground in understanding the area of policy implementation, Regional government collaboration with madrasas in raising regional potential through collaboration of character education programs, providing intensive training to teachers evenly rather than representatives, and providing coaching programs to students.

Thirdly, the implementation of character education in Madrasah Aliyah in Jambi Province. Implementation of character education in madrasas through integration of character values in learning, madrasa activities, and religious culture in madrasas. Integration in learning by including character values in 
the core competencies and basic competencies of each subject. Core competencies and basic competencies are developed in learning objectives and series of learning activities. Madrasa activities and religious culture, namely religious values through routine when students enter the madrasah area until they go home, Honest values through customizing assignments, tolerance values by inviting non-Muslim students to commemorate the big day at madrasa, Discipline through adherence to rules that give consequences and the cleanliness of madrassas, the spirit of nationalism through the commemoration of ceremonies and national holidays, the love of peace through the act of maintaining the unity and association of friends, social care through acts of social service to the phenomena that occur in the regions and Indonesia in general.

Fourthly, the implementation of national policies has not been able to reach the standards of character education in Madrasah Aliyah in Jambi Province. Every madrasa has the potential to support the application of character education, namely the Jambi MAN Model with a learning system that is supported by a dormitory. Some things that become obstacles in the implementation of character education policies in madrasah are; firstly, too fast curriculum changes and curriculum content changes. Second, educators are still too focused on the income of high scores on students' cognitive. Third, the lack of understanding of policy implementers and policy targets for priority values. Fourth, the training activities and the refresher of teachers' abilities and skills have not been maximized. Fifth, the influence of family background on student violence. Sixth, there is a typology of people who have not yet developed character education.

\section{CONCLUSION}

The results of the research could be concluded that the Character Education Policy at the State of
Madrasah Aliyah Jambi Province had been applied in the madrasas and the constraints faced in the form of a lack of human resources became uswatun khasanah figures and the lack of facilities for learning that supported the application of character education in madrasas and the lack of financial or financial support from the government in developing madrasa programs and learning programs.

\section{REFERENCES}

1. Mukhtar. (2018). Analisis Kebijakan Pendidikan: Standar Kompetensi Manajerial Kepala Sekolah/Madrasah, Jambi: Salim, 16.

2. Musa, A.M. (2009). Politik Anggaran Pendidikan Pasca Perubahan UUD 1945, Jakarta: Sekretariat Jendral dan Kepaniteraan Mahkamah Konstitusi, 27.

3. Dunn, W. N. (1988). Methods of the second type: Coping with the wilderness of conventional policy analysis. Review of Policy Research, 7(4), 720737.

4. Joesoef, S. (2012). Konsep Dasar Pendidikan Luar Sekolah, Bandung: Remaja Rosdakarya, 16.

5. Joesoef, S. (2012). Konsep Dasar Pendidikan Luar Sekolah, Bandung: Remaja Rosdakarya, 124.

6. Sumani, M. (2013). Konsep dan model pendidikan karakter, Bandung: PT Remaja Rosdakarya, 41-42.

7. Zubaedi. (2011). Desain Penddikan Karakter, Jakarta: Kencana, 74-76.

8. Baca, J. (2011). Badan Penelitian dan Pengembangan Kurikulum, Pedoman Pelaksanaan Pendidikan Karakter, Jakarta: Kemendiknas, 4047.

9. Abdurrahman, M. (2016). Akhlak Menjadi Seorang Muslim Berakhlak Mulia, Jakarta: RajaGrafindo Persada, 35-36.

10. Mustafah, J. (2015). Manajemen Pendidikan "Teori, Kebijakan, Praktik", Jakarta: Kencana, 4849. 